\title{
Learning History Through Augmented Reality
}

\author{
Bayu Prakoso Dirgantoro \\ Binus Northumbria School of Design - Graphic Design and New Media \\ Bina Nusantara University \\ Jakarta, Indonesia \\ bdirgantoro@binus.edu
}

\begin{abstract}
History has been adapted as a compulsory subject since 1931 alongside math and science. However, learning history in Indonesia could be a challenge since Indonesia placed in the second lowest of literature behaviour. For the past decades, educators have been implementing the term of in class edutainment and gamification. One of the forms of edutainment could be accomplished by Augmented Reality. This project is conducted to provide an alternative learning tool in history learning, especially for elementary school students who tend to have a negative paradigm that learning history means reading textbooks. In addition, the function of Augmented Reality will be beneficial to students and teachers in order to support multiple learning styles without losing its substance as it is based on the K13 curriculum.
\end{abstract}

Keywords-History learning, Textbook, Augmented Reality

\section{INTRODUCTION}

History is one of the forms of national education implemented in Indonesia. There are 7 major objectives of history as a school subject: (1) Developing the ability of chronological and critical thinking (2) Raising social awareness (3) Developing nationalism (4) Developing honesty, hard work, and responsibility (5) Developing curiosity (6) Developing leadership (7) Developing the ability of finding, processing, selecting, and communicating informations. [1] Referring to Kurikulum Tingkat Satuan Pendidikan (KTSP) 2006 made by Kementrian Pendidikan dan Kebudayaan Republik Indonesia (Kemendikmud), the science of history is studied in Social Study subject or Ilmu Pengetahuan Sosial (IPS) in elementary and junior high school. [2] One of the materials that is included is the story of Gajah Mada. It covers the stories about Gajah Mada's strategies expanding the area of Majapahit, or his loyalty towards his Kings. This subject is taught in fourth grade of elementary school.

Although history is a substantial subject, learning history is quite challenging for students in elementary school. History learning involved the process of understanding time in chronological order.

[3] This struggle later turns worse as students are required to read textbooks in history classes. In his research, Kasim evaluates that learning historical studies in Indonesia with textbooks is monotone and no longer effective for students [4] . Following in 2016, John Miller, president of Central Connecticut State University in New Britain, stated in his research titled The World's Most Literate Nations

Ranked that Indonesia is placing the second-lowest country based on literate behaviour [5]. This low in-class interactivity then leads into negative connotations students have towards learning history.

One of the alternative methods educators have conducted to increase in class interactivity is through edutainment. Edutainment, a learning method combining education and entertainment to enhance learning [6], was first suggested by Robert Heyman, a lecturer of American National Geography Academic Union. The practice of edutainment increases as researchers explain that an interactive learning environment can encourage passive students into fully engaged active learners [7]. Since the 1970s, the implementations of edutainment have been expanded, leaving various forms of edutainment as an alternative instrument in education. One of the most recent of edutainment is through Augmented Reality (AR).

Augmented Reality, shortened AR, defined as a new technology emphasizing at layered interfaces. Mark Billinghurst, director of Human Interface Technology Laboratory of New Zealand (HIT Lab NZ), stated that although the invention of Augmented Reality is not new, its potential in supporting education could be highly explored [8]. In addition, AR based technologies offer borderless interaction between the real and virtual world which makes it a distinct tool amongst computing technologies. One of the uses of this unique trait of $\mathrm{AR}$ is by combining AR and physical books where AR can be used to enhance a physical book by augmenting the book pages with the graphics, animations, and audio. Integrating AR concepts into a physical book will convert a static story reading experience into a dynamic, fun, and interesting reading experience [9].

The scope of this project is to create a learning kit about the history of Gajah Mada in Majapahit Empire. This learning kit will consist of a textbook, set of cards, and AR application which target, but not limited to, fourth grade elementary school students. All of the materials in this project will be delivered in Bahasa Indonesia. The purpose of this Augmented Reality based 
learning book is not as a replacement for teaching, instead it will be an alternative tool for students to learn history and an extra teaching instrument for educators.

\section{HISTORY LEARNING IN INDONESIA}

History is a study of past events, structured in scientific form, and presented in chronological order of time [10]. The education of history towards Indonesian students is important. Therefore, Indonesian history has been included in compulsory subjects taught in elementary until high school alongside science and math since 1971 .

Textbooks play a dominant role when it comes to learning history in Indonesia. Referring to Undang-Undang Republik Indonesia Nomor 20 Tahun 2003, Textbooks used in classrooms are arranged based on standardized competency of student's cognitive and literature development, meaning students with higher level of education will read more complex textbooks compared to those with lower level of education. In its practice, textbooks should not only be used as learning sources, but also a media that could engage students to be active learners. [1]

Starting from 2013, Indonesia has adapted a new learning curriculum, known as Kurikulum 2013 or K13. Through K13, students are expected to be more active in their learning process by independent activities such as finding information, processing them, and communicating them to peers or teachers. Based on K13 released by Kemendikbud on IPS, elementary students will learn about Gajah Mada in fourth grade, specifically on chapter 1 and chapter 5. [11]

Gamification is a part of edutainment educators have been using games as an alternative to teach morality and ethics. [9]. In modern education, gamification has provided immersive and interactive learning environments that could turn passive learners into active learners. In history classroom, for instance, the flexibility of games allows students to encounter historical backgrounds and settings compared to reading about them from textbooks. [12] While learning about certain eras in history, students are not able to physically be present to witness cultural processes nor experience the relationship between cause and effect. However, through games and simulation, students could indirectly interact with past situations. [13]

\section{AUGMENTED REALITY}

Augmented Reality (AR) is a new technology which was invented as a mixture of virtual world and real world. Differs from Virtual Reality (VR), AR offers users a new and distinct way to interact with the world through the art of overlaying virtual content. Through augmented reality, users could look at the real world with their device lenses, while the layered application adds images or three-dimensional objects into this particular scene. This overlaying feature is then developed by researchers into various forms of AR-based applications for different purposes, for instance, but not limited to: entertainment, lifestyle, or education. [14]

One of the earliest Augmented Reality (AR) works was brought by Mark Billinghurst, Director of the Human Interface Technology Laboratory New Zealand (HIT Lab NZ), who has produced over 80 publications related to augmented reality and computer interfaces. Recorded in his journal titled "Augmented
Reality in Education" in 2002, Billinghurst introduced his work called "MagicBook". The initial idea of "MagicBook" was combining a physical book and Augmented Reality to create a new experience for users. Using a normal book as the main object, users could turn the pages of the book, look at its pictures, or read without the help of any technology devices. However, with the help of AR, users could see three-dimensional virtual models appearing on every page. On his conclusion, Billinghurst stated that "MagicBook" is an enhanced version of a traditional "pop-up" book combined with technology. [8]

\section{DESIGN ELEMENTS}

\section{A. Bright Colors Are More Suitable for Children}

Seen from its brightness and saturation, colors are divided into two: dark and bright colors. Bright colors, mentioning yellow, orange, or light blue, appeal to children more compared to dark colors, e.g.: brown, black, maroon, etc. The Bright colors catch their attention quicker as their eyes are not fully developed yet. [15] As they sense their environment, they tend to find colors with high contrast quicker compared to low contrast color. Primary colors, consisted of red, blue, and yellow, are more appealing compared to neutral shades of grey and brown. In addition, researchers and doctors understand that color could affect children's emotion and could possibly have an intense effect on developing children's personality.

\section{B. Character Design}

Referring to a book called 'Creating Stylized Characters', there are three basic geometric shapes in creating shape language. [16] The concept of shape language is an alternative to create a distinct and unique character as a form of exaggeration. In this project, the researcher uses basic shapes as a starting point in conveying certain messages or traits through characters. A circle does not have any edges and is often used to convey something that is softer and kinder. A triangle has sharp edges and symbolizes danger or unfriendliness. Last but not least, a square came across as solid and compact, leaving a strong impression.

\section{Traits of Gajah Mada}

Although there is no proven research on the exact physical traits of Gajah Mada, we often see the depiction of him in books, statues, or temples. This depiction was an interpretation made by Mohammad Yamin back in 1945. Through his book titled "Gajah Mada: Pahlawan Persatuan Nusantara" published in 1945, Yamin depicted Gajah Mada as someone who is sharpeyed, along with a firm jawline and long hair. This depiction was later adapted in school textbooks to help students visualize the physical form of Gajah Mada in learning process.

\section{Classification in Majapahit Empire}

People with higher social class tend to wear more accessories and bright-colored outfits. The purpose of clothing between people with high social class is different compared to those with lower social class. People with lower social class used their clothes to cover and protect their body, as people with higher class used their clothes to decorate and add their personal aesthetic value. [17] 


\section{Methodology}

This research is compiled through several sources, such as: Books, Journals, Electronic Media, Interviews, and Field Survey. These sources are selected in order to give a broader overview regarding each topic discussed in each chapter and offer more perspectives to the researcher related to the final project. Aside from journals, interviews will be conducted to support this research. This interview will be taken from three different perspectives: expert, educators and target user. There are three experts interviewed in this research: Andi Taru, Angie, and Alvanov Zpalanzani Mansoor.

Andi Taru is a Game Developer for Children in Educa Studio. He is also the member of Asosiasi Game Indonesia (AGI) and is very proficient in game design area, especially if it is related to children's game. Qualitative approach is needed in order to collect several informations regarding children's game, for example, but not limited to: (1) Converting educational substances into the form of games, (2) Determining the suitable gameplay for children, (3) Designing the suitable game interfaces for children.

Angi has been entitled as Education Director of Tara Salvia School for the past 14 years. She is also a content writer of children's story book, such as "Coba Lagi, Coba Lagi", "Di Mana?", "Wuss,...Angin Membawa Telur Terbang", and "Mengapa Harus Marah?" which were published in 2015. Aside from storybooks, Angi is also a content writer of elementary school books such as, "Buku Tematik SD Kurikulum 2013, Kelas 4" as well as "Buku Tematik SD Kurikulum 2013, Kelas 6". As a content writer, Angi pays a lot of attention on how content is created, in this case: elementary school books. Since 2013, the Ministry of Education and Culture has been implying Kurikulum 2013, or known as K-13, as a replacement of Kurikulum Tingkat Satuan Pendidikan 2006, or known as KTSP 2006. There are a few differences between KTSP 2006 and K13 , and one of the major differences is how textbooks are arranged.

Alvanov Zpalanzi Mansoor is a senior lecturer at Institut Teknologi Bandung (ITB) and game designer. His recent work is Ayodya which adapts Indonesian historical figures which are: puppets. Alva has been doing research towards the visualization of puppets for the last 10 years. Ayodya is a very suitable example for this project as it adapts stories as well as characters and transforms them into a contemporary project, which is: board games

\section{IDEATION}

\section{A. Project Components}

This project consists of three main components which will complement each other, consisted of: Learning book, set of cards, and mini exhibition kit. All of the components are supported by Augmented Reality (AR).

\section{B. Stage Design}

Angela Larasati, the designer decided that the learning book is consisted of two parts, main quests and random quests. The form of random quest will be similar to quick review questions teachers ask at the end of the class. Through this way, children will have time to review the materials and understand more about the core value of history learning. The random question will be AR based, and children could record their answer through videos and send it to the teacher for small assessments if necessary.

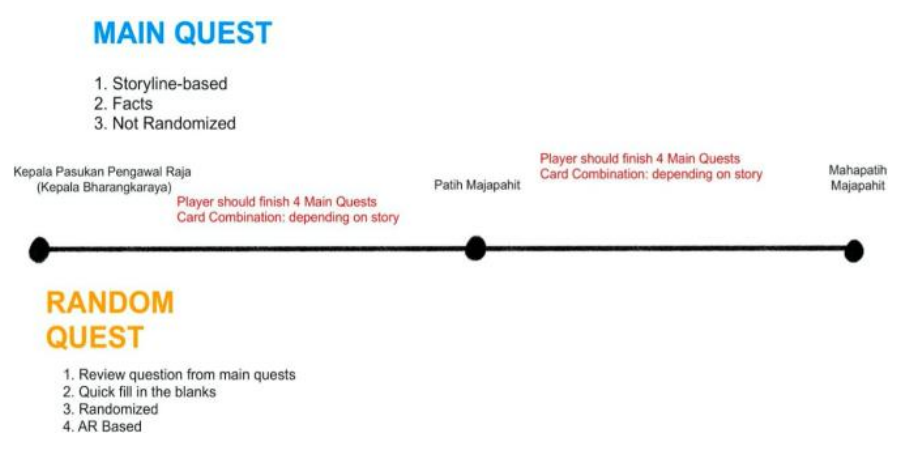

Fig. 1. Stage Design

\section{$C$. Story based stage design}

After breaking down several stages of the project, we started to develop the stage design based on the story of Gajah Mada. During the design phase, there are 3 design iterations, and each design improves the mechanic based on the previous one.

Stage Design I will divide the project into two major milestones. Gajah Mada as Pasukan Bhayangkara to Patih Majapahit, and Patih Majapahit to Mahapatih Majapahit. Between every milestone, students are required to finish a certain amount of main quest and random quest. Main quests are based on historical timeline and facts, while random quests are considered more casual. After completing every mission, users could unlock several rewards and move on into the next quest or mission.

Stage Design II will still divide this project into two milestones. Revising the first form of mechanism, the second stage design will delete the lock and unlocking feature so this project will be more flexible to be applied for multiple users. The second version of stage design contains a specified number of main quests based on historical timeline of Gajah Mada.

Stage Design III is the final form of stage design which will be applied in the project. Differing from the two previous designs, the last mechanism changes the concept of random quest. The last form of random quest will be similar to quick review questions teachers ask at the end of the class. Through this way, children will have time to review the materials and understand more about the core 52 value of history learning. The random question will be AR based, and children could record their answer through videos and send it to the teacher for small assessments if necessary.

\section{Character Design: Gajah Mada}

As the main highlight of this project is centered in Gajah Mada, the researcher decided to break down the traits of Gajah Mada and form his physical character design. Gajah Mada is known as a strong and powerful person. Therefore, adapting from the theories of basic shapes as character visual language, square shaped is chosen in order to symbolize Gajah Mada's strong personality and strength. Aside from its shape, several styles were also developed as alternatives. These alternatives 
were reviewed based on its ability to depict the initial traits of Gajah Mada.
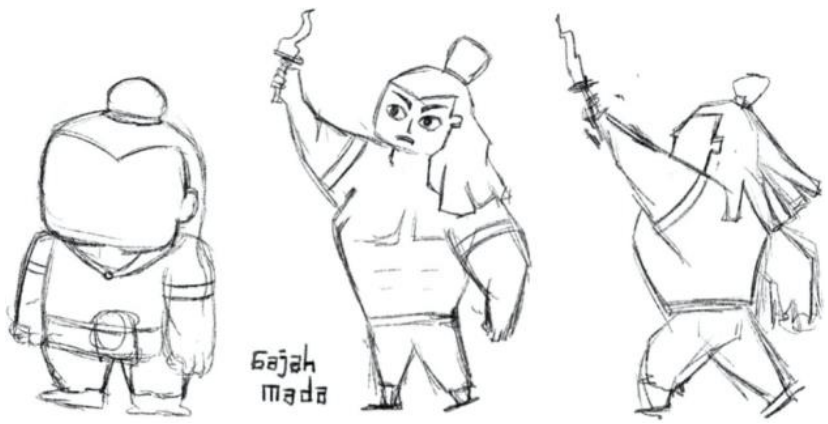

Fig. 2. Character Sketches

Seen from figure 2 , the third style (right) was chosen as it depicts a clearer silhouette and stronger impression towards the audience. Since the project is divided into three several milestones, the researcher created three different costume designs for Gajah Mada so users could visually acknowledge the higher rank Gajah Mada has earned. The fundamental concept of this design is based on the outfit concept of Majapahit. People with higher positions will have more attributes to wear.

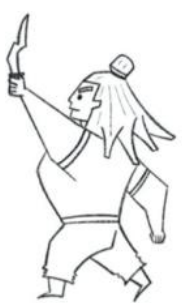

bela diri

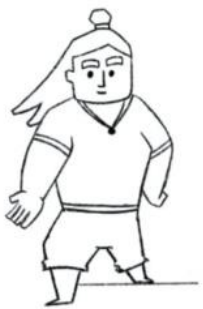

pengorbanan

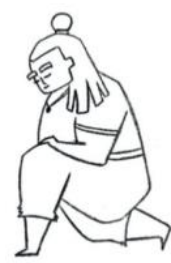

loyalitas

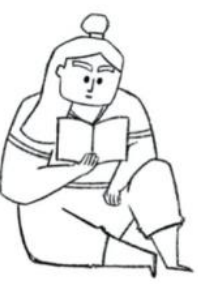

kecerdasan

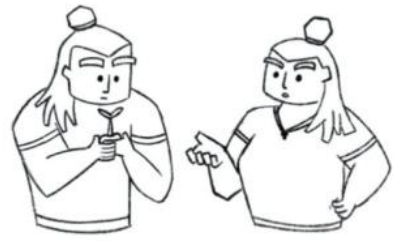

cinta lingkungan musyawarah
Fig. 3. Refined Sketches of Gajah Mada

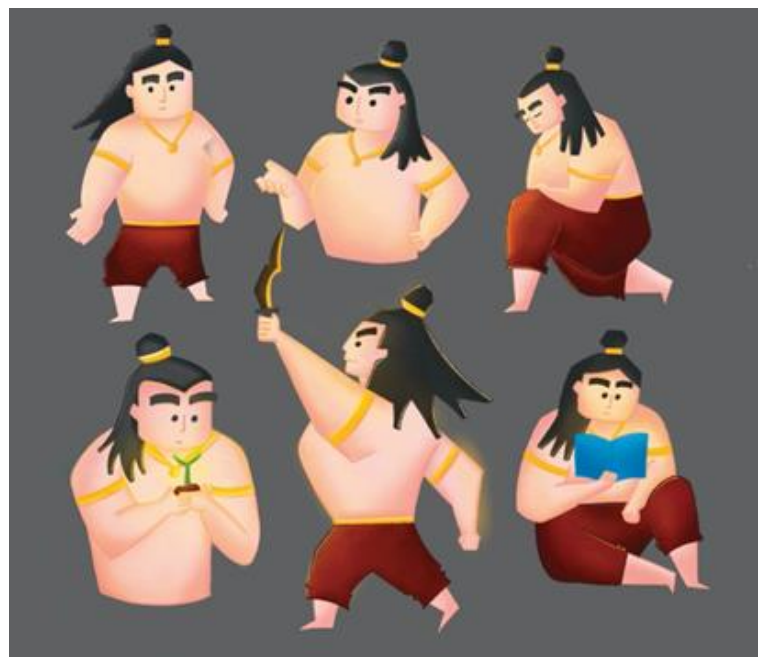

Fig. 4. Colored Version of Gajah Mada

\section{E. Character Design: Figures}

In addition to the characters, several figures were added to this project. These figures were selected from main roles in Majapahit Empire. These roles will help Gajah Mada to finish his mission in this project. The distinct element of these characters are located on how it is colored and the outfit attributes of each role. The higher the role is, the brighter clothing they will have with more attributes compared to those who have a lower class of social status.

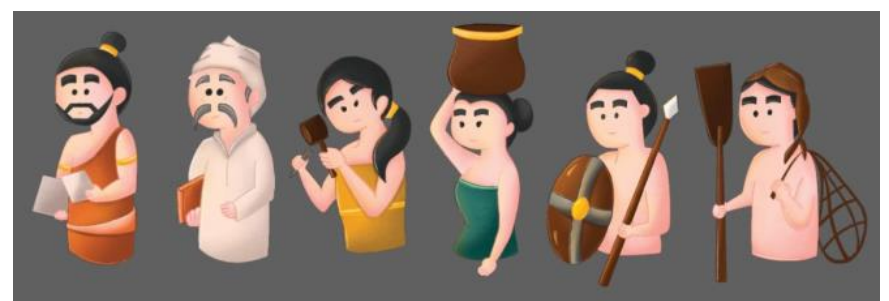

Fig. 5. Colored Version of Figures

\section{Book Layout and Development}

After the game flow was formulated and the characters were formed, the researcher continues to work on the major element of this project, the textbook. The flow of this textbook contains: scanning card tutorial, milestones, and mission pages. This learning book will be illustrated to engage more with students. 


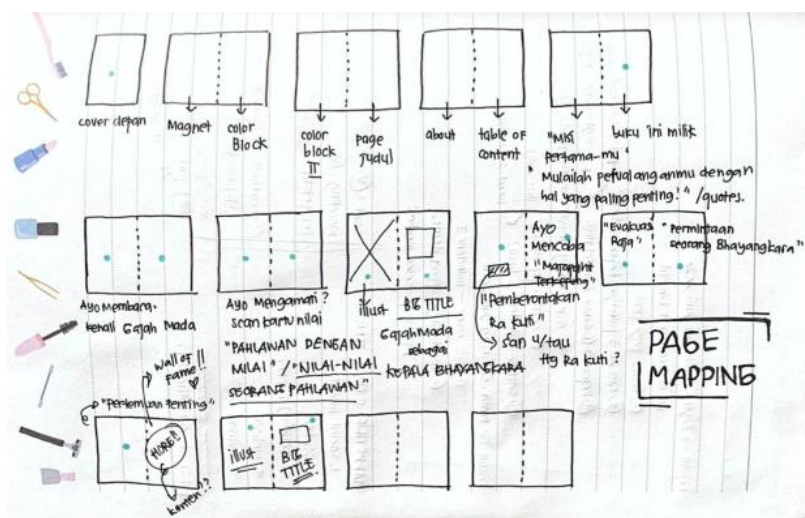

Fig. 6. Page Mapping

\section{F. Cards Development}

There are two cards provided for this learning kit. These cards will be used as an answering tool for every quest. There are value cards, and figure cards. Since the project is centered in Gajah Mada, the value cards represent the value of Gajah Mada illustrated in the form of Gajah Mada himself. Several poses are included to properly depict the value attached in the card. Aside from value cards, there are also figure cards which characters have been mentioned in the previous section. The basic ideation of this card is to associate the value/list of figures visually. This is why there are only illustrations, titles of value or figure, and information regarding whether it is a value card or figure card. Value card is presented brighter compared to figure cards since the curriculum of K13 emphasizes more on learning values in class.
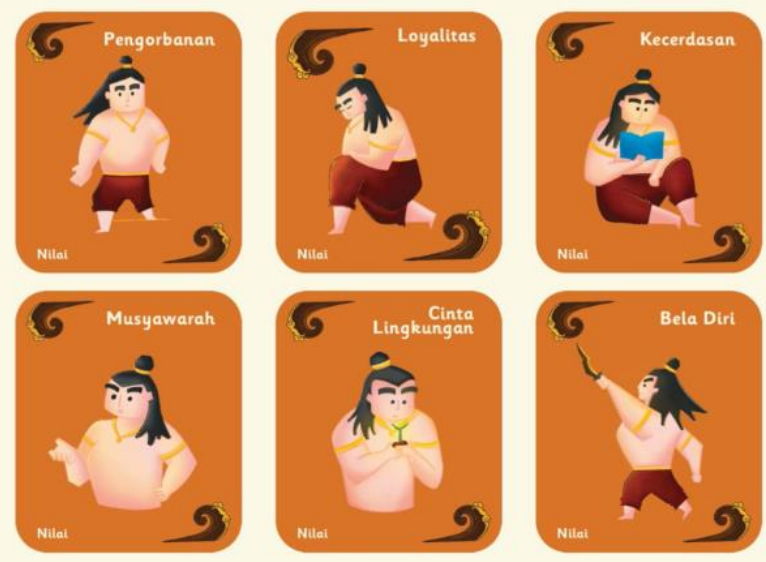

Fig. 7. Value Card
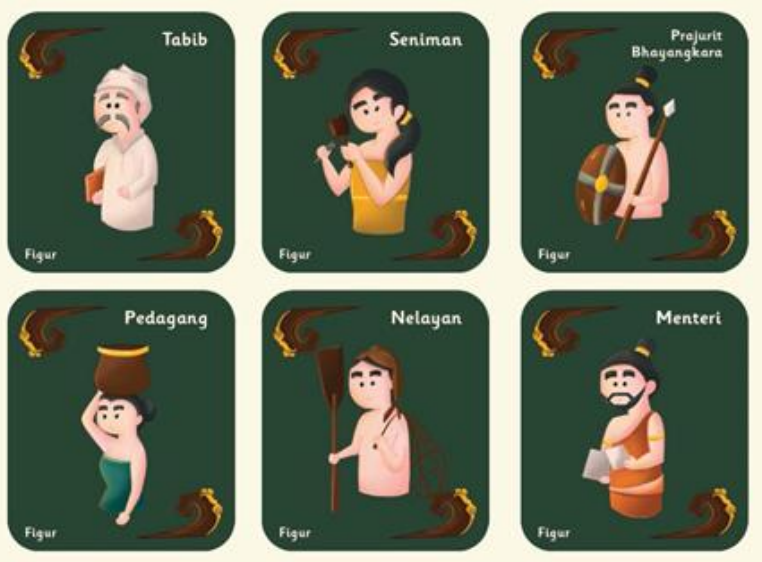

Fig. 8. Figure Card

\section{G. AR Development}

The On this project, the researcher will use an application called UniteAR to develop the work and make prototypes. UniteAR is a free to use AR application, however just like another application it has negative and positive sides. UniteAR is an AR app that includes several features such as image tracking, button tapping, panorama, sound, or even videos. It is free to use, and very easy to use since users could only drag and drop the image target and the displayed image. However, the scanning process takes up to 10 seconds. It is considered slow for an AR application.

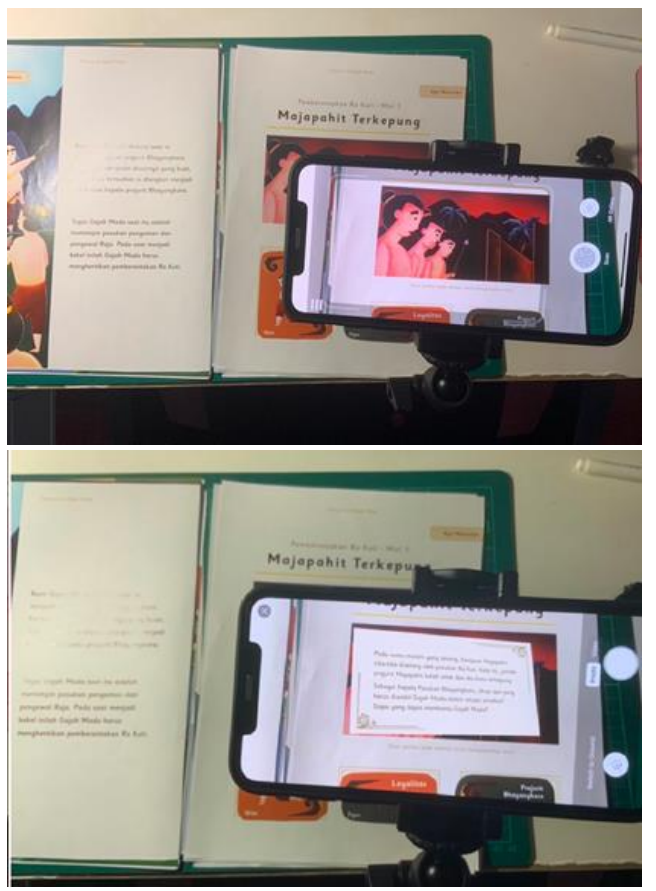

Fig. 9. Mission Scanned AR 

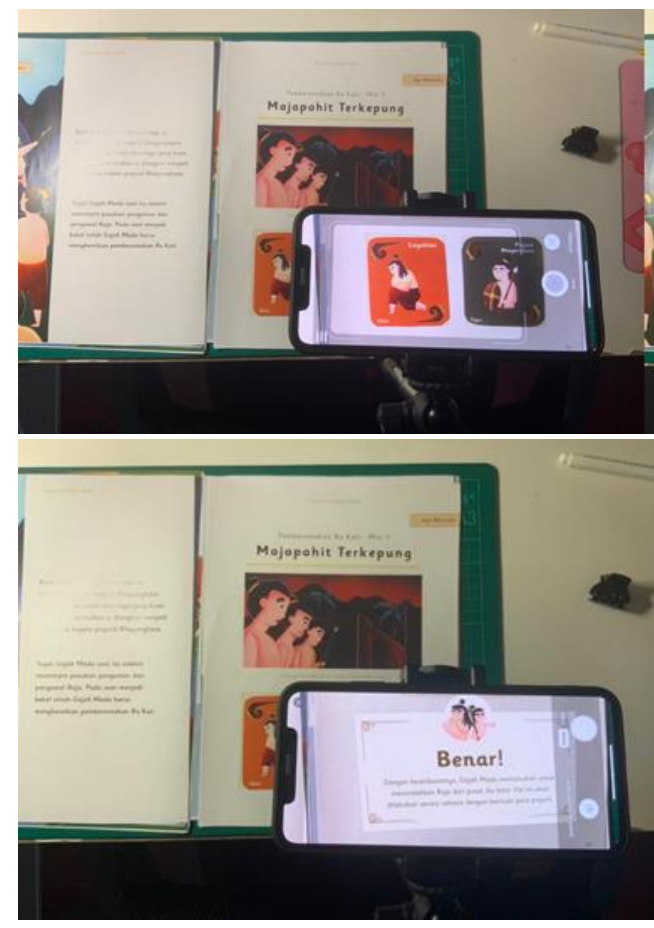

Fig. 10. Answer Result AR

\section{H. Packaging Design}

This learning kit will include a textbook and sets of cards. The packaging dimension of the book will be $21 \mathrm{~cm} \times 28 \mathrm{~cm}$, inspired from standard size school textbooks, and the dimension of the cards will be $6,5 \mathrm{~cm} \times 7,5 \mathrm{~cm}$. Since this learning kit is made for children, the cover of the learning book and cards will be made from magnet. In this condition, it will be easier for children to attach and detach the cards without having any issue of misplacing them after they have finished the activities.
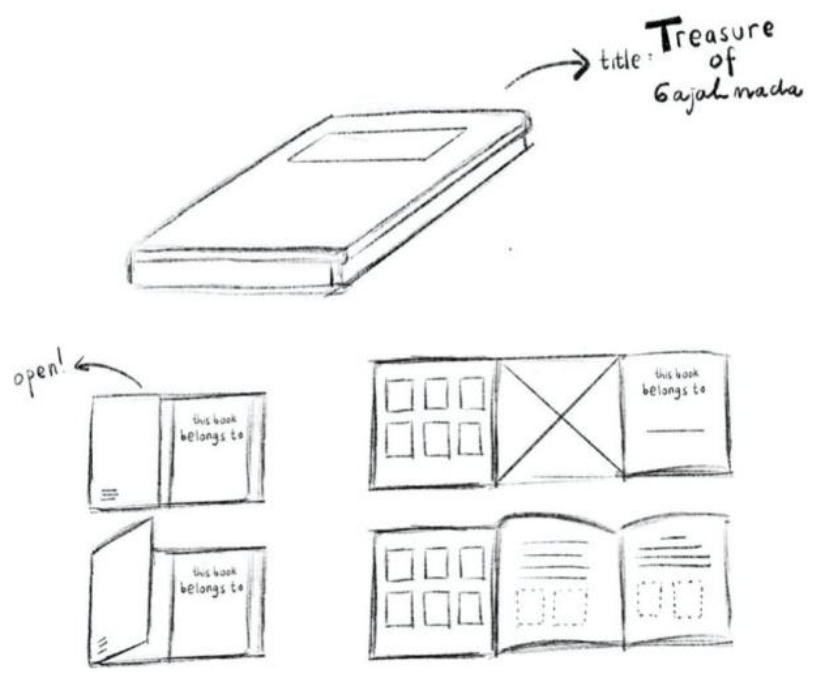

Fig. 11. Packaging Ideation

\section{CONCLUSION}

The initial ideation of this project is to give a new perspective of learning history, which could be implemented through Augmented Reality. The main target audience are, but not limited to, elementary students who learn Gajah Mada as their school curriculum. This project combines both reality and digital world, and in this journey many challenges appeared along the way, both in the form of technical issues or art block. However, technical issues placed on the top tier why this project is very challenging, starting from learning to understand $\mathrm{C \#}$ scripts, unity 3D, and AR Foundation. This project brings a new approach towards history learning and could be implemented for other historical figures which influence a major group of people or leave positive value in his or her lifetime. To increase the value of this project, the researcher wants to give a few recommendations as listed below: 1. Adding animations on the mission scanned, as it will be engaging and still require students to read the missions 2. Expansion of cards variations to make it more challenging.

\section{REFERENCES}

[1] Hasan, Said Hamid. 2012. Pendidikan Sejarah untuk Memperkuat Pendidikan Karakter . Dalam Jurnal Paramita, Vol. 22, No. 1.

[2] Kementerian Pendidikan Nasional. 2010. Pengembangan Pendidikan Budaya dan Karakter Bangsa. Bahan Pelatihan Penguatan Metodologi Pembelajaran Berdasarkan Nilai- Nilai Budaya untuk Membentuk Daya Saing dan Karakter Bangsa. Jakarta: Badan Penelitian dan Pengembangan Pusat Kurikulum.

[3] Green, Nicole \& Reitano, Paul \& Dixon, Mary. (2010). Teaching and Learning History in Primary Schools: Pedagogical Shifts, Complexities and Opportunities. International Journal of Learning. 17. 10.18848/14479494/CGP/v17i08/47200.

[4] Kasim, Melany. (2008). Model Pembelajaran IPS, (Online), Http: // Wodrpress

[5] Miller, John. (2016) World Literacy: How Countries Rank and Why It Matters. 78 New York: Routledge

[6] Katsaliaki, Korina and Mustafee, Nakonil. (2014). Edutainment for Sustainable Development: A Survey of Games in the Field. Sage

[7] Moore, A.H. Fowler, S. B. And Watson. C.E Active Learning and Technology: Designing Change for Faculty, Students, and Institutions. EDUCAUSE Review, vol. 42, no 5 September/October 2007. pp. 42-61

[8] Billinghurst, Mark \& Kato, Hirokazu \& Poupyrev, I.. (2001). The MagicBook - Moving seamlessly between reality and virtuality. Computer Graphics and Applications,

[9] Garris, R., Ahlers, R., \& Driskell, J. E. (2002). Games, motivation, and learning: A research and practice model. Simulation \& Gaming, 33(4), 441-467. doi:10.1177/1046878102238607

[10] Idris, Fadzilah. (2011). The Role of Education in Shaping Youth's National Identity. UKM Teaching and Learning Congress 2011

[11] Hakim, Lukmanul. (2017). ANALISIS PERBEDAAN ANTARA KURIKULUM KTSP DAN KURIKULUM 2013. Jurnal Ilmiah Didaktika. 17. 280. 10.22373/jid.v17i2.1644.

[12] Kee, K., Graham, S., Dunae, P., Lutz, J., Large, A., Blondeau, M., \& Clare, M. (2009). Towards a theory of good history through gaming. The Canadian Historical Review, 90(2), 303-326. doi:10.1353/can.0.0164

[13] Morgan, E. J. (2013). Virtual worlds: Integrating second life into the history classroom. The History Teacher, 46(4), 548-559. Retrieved from http://www.societyforhistoryeducation. org/ pdfs/A13_Morgan.pdf

[14] Colace, F., De Santo, M. \&Pietrosanto, A. (2006). Work in Progress: Bayesian Networks for Edutainment, 36th ASEE/IEEE Frontiers in Education Conference, DOI: 10.1109/ FIE.2006.322573

[15] Pancare, Rachel. "How Do Bright Colors Appeal to Kids?" sciencing.com, https:// sciencing.com/do-bright-colors-appeal-kids5476948.html. 13 April 2020.

[16] 3dTotalPublishing. (2018). Creating Stylized Characters. Exaggerating Shapes, 19 
[17] Mambo, Winston dan H. Nurhayati. 1992 Maulana, Ratnaesih. 19972008 Munandar, Agus Aris. 19892003 (a) 2003 (b) 2004 Makanan dan Pakaian pada Masa Majapahit. Simposium Menyongsong Tujuh Abad Majapahit tanggal 8 September 1992. Mojokerto: Departemen Pendidikan dan Kebudayaan Direktorat Jenderal Kebudayaan. Suaka Peninggalan Sejarah dan Purbakala. 